\title{
THE ROLE OF PHYSICAL THERAPY IN CANCER TREATMENT
}

\section{Mirosława Sidor, Krzysztof Jeziorski}

\author{
Pope John Paul II State School of Higher Education in Biala Podlaska
}

Sidor M., Jeziorski K. (2015), The role of physical therapy in cancer treatment. Health Problems of Civilization, 1 (9), p. $29-32$

Summary: Cancer is a very important problem in both medical and social respects. In recent years, there has been a shift in approach to oncological prevention, diagnostics and treatment. As a result, oncology has become an interdisciplinary field. Factors relevant for successful oncological treatment are: sequence, type and scope of intervention, including diagnosis of the cancer, assessment of its progression, systemic treatment, surgery, radiotherapy, supportive therapy and rehabilitation. Rehabilitation addresses the realm of psychology (psychooncology), as well as somatic and social issues.

Physical therapy is a notion inseparably related to medical rehabilitation and it encompasses a range of treatments which are based on the body's reactivity to stimuli.

The purpose of this article is to present the specific character, the methods and the role of physical therapy in oncology, as an increasingly popular strategy in medicine, which helps to improve performance and physical function in cancer patients. Physical therapy is essential in primary and secondary cancer prevention and it greatly contributes to improving the quality of life of patients and helps them recover quicker. Four basic kinds of intervention in oncological rehabilitation include: preventive interventions, restorative interventions, supportive interventions and palliative interventions. The main principle in rehabilitating a patient with an advanced cancer is progressing steadily but gradually. The primary and essential form of rehabilitation for cancer patients is movement exercise i.e. kinesiotherapy. Integration and cooperation during group exercise are also among the strategies that therapists seek to employ while working to improve the condition of patients diagnosed with cancer. Kinesiotherapy prevents pulmonary and thromboembolic complications in cancer patients. One method of physical therapy applied in cancer treatment is lymphatic drainage (massage), which improves circulation of lymph.

To sum up, physical therapy plays an increasingly important role in holistic care of cancer patients. It is indispensable and should become a standard approach, as a method of reducing the risk of complications, helping in faster recovery and limiting the economic and social costs of treatment.

Keywords: oncology, physical therapy, cancer rehabilitation, holistic care

Cancer is a very serious medical and social problem. In Poland, malicious cancers rank second as cause of death. In 2011, 26\% of deaths in men and 23\% of deaths in women were caused by cancer. In the same year, 154,000 people in Poland were diagnosed with cancer, while 320,000 other were living with cancer diagnosed within the past five years (Didkowska et al. 2013). Over the last few years, an evolution may be observed in the approach to oncological prevention, diagnosis and treatment and oncology has become a multidisciplinary field as a result of that. This holistic approach to the patient assumes a multi-dimentional care, which includes: health promotion, prevention stages I, II, III and IV, diagnostics, treatment, nursing, rehabilitation and palliative care, all based on co-operation of a team of specialists in different fields, including a doctor, a nurse, a physical therapist, a psychologist, a diagnostician, a chaplain (Pasek, Dębska 2010). For this reason, the work of physical therapist as well as their therapeutic options are based on the so called comprehensiveness, that is, a collaborative work of the specialists mentioned above, as well as working with patients and their families. Only a team of highly skilled, responsible experts working together can carry out the most difficult tasks one is faced with in treatment and rehabilitation of cancer patients (Kwolek 2009). Kamusińska argues that the composition and hierarchy of competence in such a team should depend on the specific situation of a given patient (Kamusińska 2008).

In such a system of cancer care, the goal is to attain the maximal effectiveness of treatment of cancer while maintaining safety requirements for any procedure potentially dangerous for patient's life. The following aspects are relevant in oncological treatment: sequence, type and scope of intervention, including diagnosis of tumour,

\footnotetext{
Address for correspondence: Krzysztof Jeziorski, Pope John Paul II State School of Higher Education in Biala Podlaska, Sidorska 95/97 Street, 21-500 Biała Podlaska, e-mail: krzysztof.jeziorski@wp.pl, tel. (83) 3449916

Tables: 0 Figures: 0 References: 16 Full-text PDF www.hpc.edu.pl Copyright (C) Pope John Paul II State School of Higher Education in Biała Podlaska, Sidorska 95/97, 21-500 Biała Podlaska Indexation: Index Copernicus, Database AGR0, ProQuest, Polish Ministry of Science and Higher Education. This is an open-access article distributed under the terms of the Creative Common Attribution Non-commercial license (http://creativecommons.org/licenses/by-nc/3.0), which permits use, distribution and reproduction in any medium, provided the original works is properly cited, the use is non-commercial and is otherwise in compliance with the license.
} 
assessing its progression, systemic treatment, surgery, radiotherapy, supportive treatment and rehabilitation (Warzocha 2014). Rehabilitation addresses patient's psychology (psychooncology) as well as somatic and social realms of life.

Physical therapy is a notion inseparably related to medical rehabilitation and it encompasses a range of treating methods, which make use of the body's reactivity to stimuli. Physical therapy includes the following kinds of therapy: balneotherapy, climatotherapy, hydrotherapy, kinesiotherapy, manual therapy, therapeutic massage, occupational therapy, remedial gymnastics. Physical therapy prevents progression and relapses of the disease and restores physical function. The goal of physical therapy is to prevent disease progression and relapse, remedy different ailments, and help in regaining physical function. According to Nowotny, by applying physical therapy one strives to prevent unwanted states and phenomena, to remedy or alleviate undesirable symptoms, or in case the former is impossible, to adapt the patient to functioning in everyday life in spite of the occurring disorders (Nowotny 2004, p. 30). The role of physical therapy is especially important in oncology. Its main purpose is to help patients regain self-confidence and realize that the rehabilitation is reaching its intended results, thus enabling them to achieve functional independence in life. According to Ostaszewska, physical therapy is of significant importance in primary and secondary prevention of cancer, and also greatly contributes to improving the patients' quality of life and accelerating their return to normal life (Ostaszewska 2013).

Four basic kinds of interventions are distinguished in cancer rehabilitation:

- preventive interventions aimed at reducing the negative effects of treatment,

- restorative interventions, which seek to help the cancer patient regain the original physical function and activity,

- supportive interventions, by which the patient learns to accommodate and accept the disease and the disabilities that result from it, for example learning to use prosthesis and items of daily use,

- palliative interventions, which are used in terminal stages of the disease. They are designed to alleviate different ailments and improve the patient's quality of life e.g. through pain control, preventing contractures or decubitus (Piechaczek, Kwolek 2007).

Rehabilitation for cancer patients is safe and does not have any negative effects on their health. A correctly designed programme of rehabilitation and physical therapy depends on the stage of the oncological treatment, the time passed since it ended, and the patients specific condition and needs. Existing dysfunctions or possible complications that might occur during oncological treatment must also be taken under consideration.

The main principle in rehabilitation of patients with an advanced cancer is to progress steadily but gradually (Gośliński 2011). The rehabilitation requires patience, prioritizing the goals set for it to achieve, adapt to the patient's needs, particularly in the terminal stage of the disease.

The primary and essential form of rehabilitation for cancer patients is movement exercise i.e. kinesiotherapy.

Almost every kind of exercise is used, especially passive exercise, breathing exercise, active and relaxing exercise. Kinesiotherapy should be started as soon as possible, adjusting the exercises to the patients abilities and taking regularity and correct posture into account. The exercises may be conducted individually or in group, while bearing in mind possible contraindications such as anaemia, dyspnoea, bone pain, acute nausea, elevated body temperature and cachexia. While conducting a kinesiotherapy session, a therapist should take those contraindications into account and adequately select exercises so as to achieve the intended results. In active exercises, general rehabilitation, breathing, loosening, and relaxing exercises one should always adjust the rhythm, speed and intensity to the whole group. Integration and cooperation during group exercise are also among the strategies that therapists seek to employ while working to improve the condition of patients diagnosed with cancer. Improvement in quality of life is significantly correlated to taking advantage of physical exercise during hospitalisation, and exercising may potentially shorten time spent in hospital (Kwolek et al. 2007).

A problem common for cancer patients is avoiding kinesiotherapy sessions, particularly group exercise. This results from poor psychological and physical condition of patients in that group. Among the reasons to avoid physical activity in cancer patients one might also find choosing a less demanding lifestyle, frequent and intense fatigue symptoms and decreased exercise capacity. Thus, the therapist should convince the patients that physical activity is by all means desirable in their cases. Kinesiotherapy prevents complications in the circulatory and respiratory systems, which result from prolonged immobilisation of the patient. Regular exercise under supervision of a physical therapist greatly contribute to improving the quality of life. A patient feels less tired, has a better control of their own behaviour, is less preoccupied with thoughts of fear, and does not experience anxiety about their condition too often.

Kinesiotherapy prevents pulmonary and thromboembolic complications occurring in patients diagnosed with cancer (Ostaszewska 2013). In that case, physical therapy should also be used in the form of breathing exercises, assuming drainage positions, chest clapping and applying inhalations. In antithrombotic prophylaxis, methods used should include the so called antithrombotic therapy, intermittent pneumatic compression, adequately elevated limb positioning. 
One of the methods in physical therapy used for cancer cases is lymphatic drainage (massage), aimed at improving lymph circulation. It is a special kind of gentle manual massage. It should be stressed that lymphedema occurs in majority of cancer patients, due to lymph nodes being involved or pressed by the ongoing disease process, or as a result of surgical extraction of lymph nodes. Manual lymphatic drainage is one of the key elements of antithrombotic therapy (Piotrowicz et al. 2000).

A technique used increasingly often as a supplement for comprehensive antithrombotic therapy is Kynesio Taping. There are ongoing studies meant to verify effectiveness of this method. Other methods used in physical therapy to treat lymphoedema include: intermittent pneumatic compression, gymnastics, bandaging, using elastic sleeves and stockings (Paz 2010).

Among methods used for rehabilitation of cancer patients one should mention Aquavibron massage. It is a dry massage with the use of a device equipped with a vibrating membrane. The membrane vibrates as a result of water flowing through the device under pressure. Aquavibron is used in treatment of lymphoedema. Other physiotherapeutic methods for cancer treatment include exercise in water, especially aqua aerobic recommended in particular for women who underwent mastectomy (needless to say, only after their surgical wound has healed) after consultation with the oncologist. Another form of additional physical activity for women after mastectomies, which may contribute to improving their functioning is Nordic walking. Marching with poles engages large muscle groups of the upper body, which translates into improved physical performance in women after breast amputation.

A significant problem occurring in cancer patients is constipation. In such cases, it is recommended to use classical massage of the abdominal wall so as to improve peristalsis if no contraindications apply (Pyszora 2010). Additionally, physical therapy is recommended for dyspnoea commonly occurring in advanced cancer patients (Pyszora, Wójcik 2010). Breathing exercises are recommended in particular, as a method to increase inspiratory capacity, improve elasticity of chest muscles and hence improve the mechanics of the chest to facilitate breathing.

In discussing the place and role of physical therapy in oncology, one should not omit patients staying in palliative care facilities, home hospices or nursing homes, where occupational therapy is used along with music therapy which as a relaxation technique, which positively influences the psyche of patients suffering from cancer.

\section{Conclusions}

Given the fact that the number of people suffering from cancer increases every year, one must bear in mind that it is possible, if not essential, to ensure comprehensive rehabilitation services for patients, especially in the initial stage following oncological treatment. One may safely argue that, as a result of progress in cancer treatment and developments of physical therapy methods for oncology, patients who have undergone oncological treatment may return to functioning as active members of the society. Application of physical therapy in oncology is the subject of numerous debates and studies. In the past, it was common to argue that exercise and physical therapy should be avoided in cancer patients. Today, physical therapy is seen as an essential treatment, which should become a standard approach (Wożniewski 2012). Its programme is based on experience and recommendations of medical personel, whose goal is to restore the patients former quality of life and thus help him or her return to normal life in the society. It should be borne in mind that only cooperation of a whole team of doctors, nurses and physical therapists creates favourable conditions to attain the goal of ensuring the welfare of cancer patients and providing professional help much needed in this difficult period of their lives.

It should be stressed once again that physical therapy plays a significant role in cancer treatment and is dependent on the indications of a specialised doctor, formulated after close analysis of a patients case history.

In conclusion, physical therapy plays an increasingly important role in holistic care of patients suffering from cancer.

\section{References:}

1. Barańska K. (2013), Fizjoterapia w onkologii. Głos Pacjenta Onkologicznego, nr 4, s. 14-17.

2. Didkowska J., Wojciechowska U., Zatoński Z. (2013), Nowotwory złośliwe w Polsce w 2011 roku. Centrum Onkologii Instytut im. M. Skłodowskiej-Curie, Warszawa.

3. Gośliński J. (2011), Rehabilitacja w opiece paliatywnej. W: Krakowiak P., Krzyżanowski D., Modlińska A. (red.), Przewlekle chory w domu. Fundacja Hospicyjna, Gdańsk, s. 241.

4. Kamusińska E. (2008), Znaczenie kompleksowej rehabilitacji w integracji osób niepełnosprawnych ze społeczeństwem. Studia Medyczne, t. IX , s. 83-86.

5. Kwolek A., Mazur A., Grzegorczyk J. (2007), Nowoczesna rehabilitacja w chorobach onkologicznych narządu ruchu. Przegląd Medyczny Uniwersytetu Rzeszowskiego, Rzeszów, t. V, z. 1, s. 2-4. 
6. Kwolek A. (2009), Rehabilitacja medyczna. Elsevier Urban\&Partner Wrocław, s. 32-38.

7. Nawotny J. (2004), Podstawy fizjoterapii. Wydawnictwo AWF Katowice, s. 29-40.

8. Ostaszewska J. (2013/2014), Rehabilitacja w onkologii. Publikacje Edukacyjne, www.publikacje.edu.pl, (dostęp: 17.11.2014).

9. Pasek M., Dębska G. (2010), Interdyscyplinarna opieka nad pacjentem z chorobq nowotworowa. Oficyna Wydawnicza AFM .

10. Paz A. (2010), Docenić rehabilitację onkologiczną. Medicus, nr 5, s. 16.

11. Piechaczek P., Kwolek A. (2007), Nowoczesna rehabilitacja w chorobach onkologicznych narządu ruchu. Wydawnictwo UR, Rzeszów.

12. Piotrowicz R., Ciecierski M., Jawień A. (2000), Obrzęki limfatyczne - leczenie. Przewodnik Lekarski, nr 7, s. 66-68.

13. Pyszora A. (2010), Kompleksowa fizjoterapia pacjentów z obrzękiem limfatycznym. Medycyna Paliatywna w Praktyce , t. IV, nr 1, s. 23-29.

14. Pyszora A., Wójcik A. (2010), Fizjoterapia w opiece paliatywnej. Medycyna Paliatywna w Praktyce, t. IV, nr 3, s. $159-167$.

15. Warzocha K. (2014), Koncepcja zmian systemowych w opiece onkologicznej w Polsce u progu 2015 roku. Hematologia, t. V, nr 3, s. 179-197.

16. Wożniewski M. (2012), Fizjoterapia w onkologii. Wydawnictwo Lekarskie PZWL, Warszawa.

Submitted: 17.11.2014

Accepted: 09.02.2015 